\title{
CLIMATE CHANGE AND ITS IMPACT ON INDIA: A COMMENT
}

-Preethi Lolaksha Nagaveni* and Amit

Anand ${ }^{* *}$

\begin{abstract}
$\underline{\text { Abstract }}$
"Climate change is now affecting every country on every continent. It is disrupting national economies and affecting lives, costing people, communities and countries dearly today and even more tomorrow. People are experiencing the significant impacts of climate change, which include changing weather patterns, rising sea level, and more extreme weather events. The poorest and most vulnerable people are being affected the most." - Goal 13, UN Sustainable Development Goals

In this background, the paper will look into what climate change is - How is climate change impacting India in $21^{\text {st }}$ century - who are the most affected - How can 'Development' and environmental protection co-exist - What are the laws dealing with Environment Protection (International and domestic) - Are they Capable enough to deal with the ever rising problems with regard to climate change - Is there a need for legal reforms - Specific instances where climate change has impacted lives significantly in recent times - How to tackle climate change - way forward
\end{abstract}

Keywords: Climate Change, United Nations, India, Domestic Laws, and Poverty.

\footnotetext{
*Advocate, High Court of Karnataka, Bangalore; Assistant Professor (ad hoc), National Law School of India University, Bangalore. [B.A.LL.B (Hons.) NLSIU, Bangalore, LL.M, University of Reading, U.K. Email: preethi8811@gmail.com]

** Advocate, High Court of Jharkhand, Ranchi; Assistant Professor (ad hoc), National Law School of India University, Bangalore. [B.A.LL.B (Hons.) NLSIU, Bangalore, LL.M, University of Reading, U.K. Email: anandamit.12@gmail.com]
} 


\section{Introduction:}

A key component of global policy making today is to combat the harmful effects of climate change on our environment. Climate change as a phenomenon has grabbed the attention of the whole world mainly because it is something that mankind has been held responsible for. ${ }^{1}$ Earth's climate is always changing. However, in the last hundred years, earth's climate has changed drastically. The earth's temperature has become warmer than before and it has had almost immediate effects on coastal areas, small islands, food security, health etc. ${ }^{2}$ In some way or the other, the whole problem of climate change has more to do with the way human beings have been conducting their lives, mostly in the era of urbanization and industrialization. ${ }^{3}$ Despite the very recent attention of the global community towards this problem, the debate on climate change has thankfully begun and is likely to get more and more complex as one tries to find answers to solve the problem. But, no debate on climate change can take place if it does not take within its fold the phrase 'responsibility for damage to the environment'. ${ }^{4}$ Countries have debated the issue, that, who should take responsibility for the damage that has already been done to the environment and is it possible to bring climate change within a legal framework so that further damage can be avoided. Note that, for any action to prevent further damage to the environment, countries both developing and developed, first need to look to their domestic laws and policies. Especially, developing countries may have to shoulder the burden a bit more because on one hand they have to balance growth and on the other climate related issues.

Therefore, in light of the above, this paper looks at impact of climate change on India through a legal perspective. The paper begins by briefly discussing climate change. The following section highlights the impact of climate change on India through the help of recently occurred climate related events. The next section mentions of the current legal framework that is in place to address the issue of climate change in India. In addition, emphasis is also placed on outlining the international response to climate change, followed by a conclusion.

\footnotetext{
${ }^{1}$ Venkatachalam Anbumozhi and others (eds), Climate Change in Asia and the Pacific: How Can Countries Adapt? (1 $1^{\text {st }}$ edn, Sage Publication India Pvt Ltd 2012) 235.

${ }^{2}$ Sunjoy Joshi and Marlies Linke (eds), Sustainable Development and Climate Change (1 ${ }^{\text {st }}$ edn, Academic Foundation 2011) 244.

${ }^{3}$ Eric A. Posner and Cass R. Sunstein, Climate Change Justice (2008) 96 (5) Georgetown Law Journal 1565 , 1567.

${ }^{4}$ Malgosia Fitzmaurice, Responsibility and Climate Change (2010) 53 German Yearbook of International Law $89,89$.
} 
The primary aim of the paper is to only look at the effects of climate change on India through a legal perspective. This paper will not cover the following; in-depth analysis of the various environmental laws in India, the socio, political and economic angle pertaining to climate change in India, the impact of climate change on countries other than India and their responses, comparative analysis of the situation in India with that of any other developing country.

This paper adopts the doctrinal approach as the topic necessitates the study of laws on climate change as it exists today. The nature of argument used in this paper is both explanatory as well as prescriptive.

\section{An Overview:}

"Climate change is now affecting every country on every continent. It is disrupting national economies and affecting lives, costing people, communities and countries dearly today and even more tomorrow. People are experiencing the significant impacts of climate change, which include changing weather patterns, rising sea level, and more extreme weather events. The poorest and most vulnerable people are being affected the most. ",

The United Nations Framework Convention on Climate Change (hereinafter UNFCCC), which provides an outline to the parties to address the causes of climate change, defines climate change as "a change of climate which is attributed directly or indirectly to human activity that alters the composition of the global atmosphere and which is in addition to natural climate variability observed over comparable time periods." ${ }^{6}$ Simply put, climate change or global warming is an increase in global average temperatures that will have a largely negative effect on ecosystems across the world. ${ }^{7}$ The overexploitation of natural resources and increasing environmental pollution has already triggered the harmful effects of climate change on people's lives. A rise in global average temperatures is likely to only worsen the current condition of human health and safety. ${ }^{8}$

\footnotetext{
5 'Goal 13: Take urgent action to combat climate change and its impacts' (United Nations Sustainable Development Goals) <http://www.un.org/sustainabledevelopment/climate-change-2/> accessed 18 November 2016.

${ }^{6}$ United Nations Framework Convention on Climate Change 1992, art 1.

7 'Report of the Office of the United Nations High Commissioner for Human Rights on the relationship between climate change and human rights' (Human Rights Council, 15 January 2009) <https://documents-ddsny.un.org/doc/UNDOC/GEN/G09/103/44/PDF/G0910344.pdf?OpenElement> p. 2 accessed 18 November 2016.

${ }^{8}$ Shibani Ghosh, Demystifying the Environmental Clearance Process in India (2013) 6 (3) NUJS Law Review 433, 433.
} 
In addition, it is believed that, billions of people, over the next few decades, mainly those living in developing countries will have to face acute shortages of water, food and greater risks to health and life as a result of harmful effects of climate change. 9 "Climate change can manifest itself in many ways and can have profound implications on the physical and biological systems of aquatic, terrestrial, and marine environments. The projected hazards of the phenomenon of climate change include diseased crop yields, the disappearance of glaciers, extreme weather conditions like floods, droughts and storms, increased coastal flooding and species extinctions." ${ }^{10}$ It is estimated that, by 2020, approximately 250 million people in Africa alone could be exposed to a greater risk of water shortage; in addition, melting of glaciers will lead to an increased risk of floods of coasts globally with some small island states probably facing total inundation. Furthermore, climate change is expected to have far reaching effects on people in developing countries because they have fewer resources to adapt effectively. ${ }^{11}$

It is clear that the issue of climate change raises difficult questions of science and economics, which have been debated widely over the years. What has been ignored for long is the legal side of the problem of climate change, which is equally significant. In this background, an attempt is made in this paper to analyze climate change and its impact on India from a legal perspective.

\section{Climate Change and India:}

One of the major areas that will be impacted by climate change in its extremity in the near future is South Asia, especially India mainly because of its diverse terrain. ${ }^{12}$ Climate change is expected to have a serious impact in this region as the country is rapidly exhausting its natural resources thereby destroying its environment mostly due to "urbanization,

\footnotetext{
9 'Climate Change: Impacts, Vulnerabilities and Adaption in Developing Countries' (United Nations Framework Convention on Climate Change, 2007) <https://unfccc.int/resource/docs/publications/impacts.pdf> p. 5 accessed 18 November 2016.

${ }^{10}$ Autri Saha and Karan Talwar, India's Response to Climate Change: The 2009 Copenhagen Summit and Beyond (2010) 3 NUJS Law Review 159, 160. See also, ibid 8 - "Rising fossil fuel burning and land use changes have emitted, and are continuing to emit, increasing quantities of greenhouse gases into the Earth's atmosphere. These greenhouse gases include carbon dioxide $(\mathrm{CO} 2)$, methane $(\mathrm{CH} 4)$ and nitrogen dioxide (NO2), and a rise in these gases has caused a rise in the amount of heat from the sun withheld in the Earth's atmosphere, heat that would normally be radiated back into space. This increase in heat has led to the greenhouse effect, resulting in climate change. The main characteristics of climate change are increases in average global temperature (global warming); changes in cloud cover and precipitation particularly over land; melting of ice caps and glaciers and reduced snow cover; and increases in ocean temperatures and ocean acidity - due to seawater absorbing heat and carbon dioxide from the atmosphere."

11 'Climate Change: Impacts, Vulnerabilities and Adaption in Developing Countries' (n 9) 5.

12 Tony George Puthucherril, Climate Change, Sea Level Rise and Protecting Displaced Coastal Communities: Possible Solutions (2012) 1 Global Journal of Comparative Law 225, 227.
} 
industrialization and economic growth." ${ }^{13}$ India faces an alarming environmental and socioeconomic challenge in its effort to protect its fast depleting natural resources. Water and air quality are worsening day by day due to increase of various pollutants in the atmosphere. In addition, the sectors that will be subjected to the highest exposure to climate change are the country's coastal eco-systems, biodiversity and agricultural productivity. ${ }^{14}$

Besides, the region is already subject to natural hazards, such as the 2013 Uttarakhand floodslandslides, the 2015 Chennai flood and the 2016 drought. There is also an evidence of prominent increases in the intensity and/or frequency of many extreme weather events such as heat waves, extended dry spells and intense rainfall. The adverse impacts of such disasters range from hunger, vulnerability to diseases, loss of income and livelihoods. ${ }^{15}$ As per the World Bank, an increase of $2^{\circ} \mathrm{C}$ in the world's average temperature in the next few decades will only make India's monsoon more unpredictable. The shift in rain patterns across India is predicted to leave a number of areas under water and others without enough water even for drinking. ${ }^{16}$ "In India, more than $60 \%$ of the crop area is rain-fed, making it highly vulnerable to climate-induced changes in precipitation patterns. It is estimated that by the $2050 \mathrm{~s}$, with a temperature increase of $2^{\circ} \mathrm{C}-2.5^{\circ} \mathrm{C}$ compared to pre-industrial levels, water for agricultural production in the river basins of the Indus, Ganges and Brahmaputra will reduce further and may impact food adequacy for some 63 million people."17

A warmer climate is also expected to slow down the poverty reduction rate. Though climate change will affect everyone's lives in the region, it is the poor who will be the most affected as they are the once largely dependent on rain-based agriculture and have no or minimal resources to sustain their livelihood. An increase of $2^{\circ} \mathrm{C}$ by the 2040 s is going to hit crop production in South Asia too and will reduce the crop output by $12 \%$, requiring more imports to meet demands at home. Also, decreasing food availability would give rise to considerable

\footnotetext{
${ }^{13}$ Saha and Talwar (n 10) 160.

14 'Climate Change: Impacts, Vulnerabilities and Adaption in Developing Countries' (n 9) 20.

${ }^{15}$ Shreerupa Mitra Jha, 'Natural disasters cost India \$3.30bn in 2015: Here's why we should be very worried' (Firstpost, 2016) <http://www.firstpost.com/india/natural-disasters-cost-india-3-30bn-in-2015-heres-why-weshould-be-very-worried-2622940.html> accessed 18 November 2016.

16 'Warming Climate in India to Pose Significant Risk to Agriculture, Water Resources, Health, says World Bank Report' (The World Bank, 19 June 2013) <http://www.worldbank.org/en/news/pressrelease/2013/06/19/warming-climate-india-pose-significant-risk-agriculture-water-resources-health-says-worldbank-report> accessed 19 November 2016.

${ }^{17}$ ibid. - "Possible Impacts for India: 1 . An extreme wet monsoon that currently has a chance of occurring only once in 100 years is projected to occur every 10 years by the end of the century. 2. Kolkata and Mumbai are 'potential impact hotspots' threatened by extreme river floods, more intense tropical cyclones, rising sea levels and very high temperatures. 3. Significant reduction in crop yields predicted. Some 63 million people may no longer be able to meet their caloric demand. 4. Decreasing food availability can also lead to significant health problems. 5. Substantial reduction in the flow of the Indus and Brahmaputra in late spring and summer."
} 
health problems especially among women and children. ${ }^{18}$ Melting of glaciers and loss of snow present a significant risk to reliable water resources in India. Main rivers such as the Ganges, Indus and Brahmaputra, depend significantly on snow and glacial melt water, which makes them all the more susceptible to adverse impacts of global warming. This could further increase the risk of flooding of low areas and pose a threat to agriculture. ${ }^{19}$

Having briefly looked into the impact of climate change, the following section will focus upon some of the recent weather events that were mostly a direct result of climate change in India.

\section{Uttarakhand Disaster 2013:}

On 16 June 2013, the state of Uttarakhand witnessed one of the worst disasters in recent times that caused extensive damage and destruction to both life and property. The state was hit by very heavy rainfall and flash floods. Every district in the state was affected. The five worst hit districts of the state were Bageshwar, Chamoli, Pithoragarh, Rudraprayag and Uttarkashi. ${ }^{20}$ The disaster took place in the peak tourist and pilgrimage season that led to an increase in the number of casualties and also affected the speed of the rescue and relief operations. The impact of the disaster was most evident in the Mandakini valley of the Rudraprayag district. ${ }^{21}$ Torrential rains led to flooding at the Kedarnath Shrine and the adjacent areas. Several other pilgrimage centers in the state, including Gangotri, Yamunotri and Badrinath, which are also popular among thousands of devotees during the summer season, were affected. ${ }^{22}$ People were left stranded for days and had to take shelter in the mountains. Over one lakh people were stuck in various regions due to damaged roads, landslides and flash flood-induced debris. As per official reports of the State Government on 09 May 2014, a total of 169 people died and 4021 people were reported missing or presumed to be dead. ${ }^{23}$ Note that, according to a report published by the American Meteorological Society, the 2013 Uttarakhand floods were mostly the consequence of "human-induced"

\footnotetext{
${ }^{18} \mathrm{ibid}$. - "The future that scientists have envisioned in this report reinforces the fact that climate change hits the poor the hardest and that it could roll back decades of development gains in India. In order to minimize the impacts of a changing climate, we need to ensure that our cities become climate resilient, that we develop climate-smart agriculture practices, and find innovative ways to improve both energy efficiency and the performance of renewable energies, Onno Ruhl, World Bank country director in India."

${ }^{19}$ ibid.

${ }^{20}$ Dr. Satendra and others, 'India Disaster Report 2013' (National Institute of Disaster Management, 2014)

<http://nidm.gov.in/PDF/pubs/India\%20Disaster\%20Report\%202013.pdf〉 accessed 19 November 2016.

${ }^{21}$ ibid.

22 ibid.

${ }^{23} \mathrm{ibid}$
} 
climate change. ${ }^{24}$ Though the report did not directly say that climate change is the reason behind the floods but it certainly pointed in that direction. On the basis of statistical analysis, the report says that the high rainfall recorded in June 2013 was a century-scale event and that climate change can be held responsible for increased likelihood of such extreme events. ${ }^{25}$

\section{Chennai Floods 2015:}

"The city of Chennai recorded multiple torrential rainfall events during November-December 2015 that inundated the coastal districts of Chennai, Kancheepuram and Tiruvallur, and affected more than 4 million people with economic damages that cost around US\$3 billion." 26 As per the Deputy Director General of the Delhi based Centre for Science and Environment, the Chennai floods were the direct outcome of the increasing global temperature breaking a 100 year old record with one day's rainfall covering a month's average. ${ }^{27}$

\section{Drought of 2016:}

India experienced one of its driest two-year periods in 2016 that affected almost the entire country. Temperatures went past 51 degrees centigrade during the month of May in the state of Rajasthan. ${ }^{28}$ Going by the national drought assessment, the country experienced a moisture deficit of at least $50 \%$ when compared to previous years. In addition, as per the Central Water Commission, water level in India's 91 reservoirs were at their lowest in almost a decade and during the month of May, stood at only $17 \%$ of their total storage capacity. ${ }^{29}$ The worst affected region in the country due to severe drought was Marathwada, Maharashtra. For the last five years this region witnessed a continuous depletion of water, indebtedness and an

\footnotetext{
${ }^{24}$ Stephen C. Herring and others (eds), 'Explaining Extreme Events of 2013 From A Climate Perspective' (American Meteorological Society, $\quad$ September 2014 ) <http://www.geos.ed.ac.uk/homes/ghegerl/Bams2014.pdf> p. 58 accessed 19 November 2016.

25 ibid 28. - Uttarakhand Disaster, "The natural instability and fragility of the land mass, coupled with ecological degradation, unwarranted changes of landscape under impact of various developmental and engineering projects, and faulty housing practices in the region makes it more vulnerable and prone to disasters. Given the circumstances of socio-economic vulnerability, slight disturbances in the sensitive zones, either due to human induced activities or other natural causes, can also lead to disasters. Unscientific development and land-use practices, poor socio-economic conditions, deforestation, increasing tourism, etc. have also contributed to the factors governing vulnerability of people of the region to disasters."

${ }^{26}$ Balaji Narasimhan and others, 'Chennai Floods 2015: A Rapid Assesment' (Interdisciplinary Centre for Water Research Indian Institute of Science, Bangalore, May 2016) $<$ http://itra.medialabasia.in/img/Chennai\%20Floods-Rapid\%20Assessment\%20ReportMay\%2023,\%202016.pdf> p. 3 accessed 20 November 2016.

27 'Chennai rain result of global warming' (Indian Express, December 2015) $<$ http://indianexpress.com/article/india/india-news-india/chennai-rain-result-of-global-warming-indian-experts/> accessed 20 November 2016.

28 Keith Schneider, 'India's Severe Drought Causing Havoc' (Circle of Blue, June 2016) <http://www.circleofblue.org/2016/world/indias-severe-drought-causing-havoc/> accessed 21 November 2016. ${ }^{29}$ ibid.
} 
increase in farmer suicides. ${ }^{30}$ Erratic climatic patterns have affected the region's agriculture, which is primarily rain-fed. No or minimal availability of water in dams, no fodder for cattle, no capital to start allied businesses and unemployment are some of the other problems faced by the people in this region. ${ }^{31}$ Over the period of last few years, agriculture in Maharashtra has been hit by extreme weather events like, hailstorms, heat wave, frost and erratic rains. ${ }^{32}$ Moreover, the heat wave in India during 2013 caused the reduction of almost four million tons of wheat production. An increase of one degree in temperature during the flowering stage in that same year also led to a huge loss to the farmers in Marathwada. ${ }^{33}$

\section{The Most Affected:}

It is almost clear that whenever there is a natural or a man-made disaster, be it floods as a result of illegal constructions in the case of Uttarakhand or the Chennai rains where there were no adequate arrangements made for the rain water to flow out of cities or the recent drought which saw an increased number of deaths, the brunt of it will be borne by the poor, the weak and the underprivileged. The above-mentioned instances in recent past have mirrored the same. The rich, the powerful sections of society have most often been the reasons for the disasters and the underprivileged have been the victims of it. They hardly have any means to approach the courts and seek justice. Where the state fails and judiciary sits silent over the pressing issues of vital importance like climate change, there will be anarchy and desperate people end up committing suicides like the farmers in Maharashtra who died due to drought. Big Corporate Houses, which contribute to large-scale pollution of air and water, escape with the mere 'corporate social liability' clauses. ${ }^{34}$ The laws have not been stringent enough to bring the culprits to justice. The authorities will not be prosecuted for dereliction of duties. Cases, which do manage to reach the Apex Court by means of Public Interest Litigations, only manage to bring about a small change in averting future crisis. Year after year India has been facing various issues as a result of climate change but we have not learnt any lessons from our past mistakes.

\footnotetext{
${ }^{30}$ Shraddha Ghatge, 'Marathwada's drought: How climate change has destroyed agriculture and ruined farmers' (Firstpost, April 2016) <http://www.firstpost.com/india/marathwadas-drought-how-climate-change-hasdestroyed-agriculture-and-ruined-farmers-2736992.html> accessed 21 November 2016.

${ }^{31}$ ibid.

32 ibid. - "Hailstorms, which are common in March, generally occur in isolated places for a couple of days. However, in the last two years, hailstorms have occurred in several parts of the state, on larger areas and for longer duration. Such impacts are likely to compound the problems of the agriculture sector, which is already struggling with severe water crisis."

33 ibid.

${ }^{34}$ Companies Act, 2013, sec. 135. Schedule VII of the Act and Companies CSR Policy Rules 2014
} 


\section{Existing Legal Framework on Climate Change in India:}

In India, there is no specific legislation in place to combat the effects of climate change. Hence, in the absence of a specific legislation, the most crucial legislation that comes close to tackling the problem of climate change is the Air (Prevention and Control of Pollution) Act $1981^{35}$ (hereinafter Air Act) enacted by the Parliament under Article 253 of the Constitution of India. ${ }^{36}$ The Air Act is important in the sense that, it provides for the prevention, control and abatement of air pollution as the presence of air pollutants in the atmosphere is injurious to human beings or other living creatures and plants. ${ }^{37}$ Thus, by talking of a direct link between air pollution and its effect on the whole environment, the Air Act addresses a key area related to climate change. Note that, the Air Act, however, does not mention the term 'Climate Change'. ${ }^{38}$ The primary objective of the Air Act is to preserve the quality of air by controlling the emission of greenhouse gases that raises the air temperature and leads to global warming. The Air Act provides for the establishment of Central and State Control Boards to look into matters related with the improvement of air quality, monitoring activities and enforcement through fine and criminal prosecutions. ${ }^{39}$

State Governments can also designate particular areas as 'air pollution control areas' and every industrial operator within that area is required to obtain prior consent from the State board before establishing or operating any industrial plant in such area. ${ }^{40}$ The State boards in consultation with the Central boards can also lay down standards for emission of air pollutants from plants and automobiles. ${ }^{41}$ Further, under the Air Act, a Metropolitan Magistrate or Judicial Magistrate of First Class is empowered to restrain an air polluter from discharging emissions, after an application has been made by the Board and allows the Board to close down an industry, or withdraw its supply of power or water, if the directions of the Board are not followed. ${ }^{42}$ The parliament also passed the Water (Prevention and Control of Pollution) Act, 1974 (hereinafter Water Act) prior to the Air Act. The Water Act provides for

\footnotetext{
35 The Air (Prevention and Control of Pollution) Act 1981.

36 The Constitution of India, art 253. -"Legislation for giving effect to international agreements Notwithstanding anything in the foregoing provisions of this Chapter, Parliament has power to make any law for the whole or any part of the territory of India for implementing any treaty, agreement or convention with any other country or countries or any decision made at any international conference, association or other body."

${ }^{37}$ The Air (Prevention and Control of Pollution) Act 1981, sec. 2 (a).

38 The Air (Prevention and Control of Pollution) Act 1981.

39 The Air (Prevention and Control of Pollution) Act 1981, sec. 3, 4 and 28.

40 The Air (Prevention and Control of Pollution) Act 1981, sec. 19.

${ }^{41}$ The Air (Prevention and Control of Pollution) Act 1981, sec. 17 (1) (g).

42 The Air (Prevention and Control of Pollution) Act 1981, sec. 22 A.
} 
the prevention and control of water pollution. ${ }^{43}$ Note that, both Water and Air Act have similar provisions with respect to achieving their said objectives. ${ }^{44}$

After the Water and Air Act, the parliament enacted the Environment (Protection) Act, 1986 (hereinafter EPA) to fill in the gaps left in India's core body of environmental law. The purpose of the EPA is to provide for the protection and improvement of the environment. ${ }^{45}$ The Government can also lay down emission standards, which are to be found in the Schedules appended to the Environment (Protection) Rules, 1986 (hereinafter EPR). ${ }^{46}$ Furthermore, the rules framed under the EPA also lay down emission norms for specific industries as well as general emission standards. ${ }^{47}$ Schedule VII of the EPR deals with National Ambient Air Quality Standards, which provides for "separate standards and concentrations for industrial, residential, and rural areas and sensitive regions and are intended to protect public health, vegetation, with an adequate margin of safety." 48 The Central Government also enacted the Ozone Depleting Substances (Regulation and Control) Rules, 2000, in exercise of its powers conferred by Sections 6, 8 and 25 of the EPA. ${ }^{49}$ The rules prohibit any person from production and consumption of ozone depleting substances and from importing or exporting to any country without a license issued by the authority. ${ }^{50}$ As noted above, there remains an absence of a core legal regime focusing on climate change in India. Nonetheless, in the absence of a comprehensive legislation, as and when climaterelated claims have reached the courts, the judiciary has been proactive in protecting the environment. However, the number of climate-related claims reaching the courts is very less. $^{51}$

\section{Climate Change Litigation in India:}

The Supreme Court of India by broadly construing the meaning of Article 21 of the Constitution has made an attempt to address challenges arising from climate change. ${ }^{52}$ Article

\footnotetext{
${ }^{43}$ The Water (Prevention and Control of Pollution) Act, 1974.

${ }^{44}$ Saha and Talwar (n 10) 184.

45 The Environment (Protection) Act, 1986.

46 The Environment (Protection) Rules, 1986, rule 3.

47 ibid.

${ }^{48}$ Saha and Talwar (n 10) 184.

49 The Ozone Depleting Substances (Regulation and Control) Rules, 2000.

50 The Ozone Depleting Substances (Regulation and Control) Rules, 2000, rules 3, 4 and 5.

${ }^{51}$ Jolene Lin, Litigating Climate Change in Asia, (2014) 4 Climate Law 140, 146.

52 ibid.
} 
21 of the Indian Constitution ${ }^{53}$ has been held to include the right to enjoy pollution free air and water for full enjoyment of life. ${ }^{54}$ The Supreme Court in the Kedia Leather \& Liquor Ltd., case held that, "environmental, ecological, air and water pollution amount to violation of the right to life assured by Article 21 of the Constitution. Hygienic environment is an integral facet of healthy life. Right to live with human dignity becomes illusory in the absence of humane and healthy environment." ${ }^{55}$ Note that, "in order to protect 'life', in order to protect 'environment' and in order to protect 'air, water and soil' from pollution, the Supreme Court, through its various judgments has given effect to the rights available to the citizens and persons alike, under Article 21. In the matter of enforcement of fundamental rights under Article 21, under public law domain, the Court, in exercise of its powers under Article 32, has awarded damages against those who have been responsible for disturbing the ecological balance either by running the industries or any other activity, which has the effect of causing pollution in the environment. The Court while awarding damages also enforces the 'Polluter Pays Principle', which is widely accepted as a means of paying for the cost of pollution and control." 56

\section{International Community and Climate Change:}

\section{UNFCCC-}

The United Nations Framework Convention on Climate Change (UNFCCC) is an international treaty adopted in 1992 by 197 countries. ${ }^{57}$ The treaty was set up to look into global warming and to prepare for its effects (e.g. temperature change and other climatic events). The UNFCCC sets out an agreement, which calls for international community to come together in the interest of human safety to tackle the challenges posed by climate change. Parties to the Convention recognize that the climate is a shared resource whose stability is of utmost importance and that it can be affected by emissions of carbon dioxide and other greenhouse gases. ${ }^{58}$ One of the achievements of the UNFCCC has been to "establish a reporting framework which provides information on greenhouse gases emissions and removals using common categorization and definitions. This framework encourages

\footnotetext{
53 ibid.

${ }^{54}$ State of M.P. v. Kedia Leather \& Liquor Ltd., (2003) 7 SCC 389.

55 ibid.

${ }^{56}$ Surendra Malik and Sudeep Malik, Supreme Court on Environment Law ( $1^{\text {st }}$ edn, Eastern Book Company 2015) 6. See also, M.C. Mehta v. Kamal Nath, (2000) 6 SCC 213.

57 'United Nations Framework Convention on Climate Change' <http://unfccc.int/essential_background/convention/items/6036.php> accessed 21 November 2016. 58 ibid.
} 
reporting of data from most of the countries that are party to the Convention. This data provides essential input to:

1. Climate scientists (looking at the relationship of greenhouse gas emissions, temperature change and other environmental factors) in predicting whether climate change and the speed of climate change pose a significant risk to humans or the environment.

2. Track progress in historical emissions and removal trends.

3. Prioritize actions for emission reduction." 59

\section{Kyoto Protocol-}

It was the first legally binding international agreement to mandate countries to reduce greenhouse-gas emissions. Countries first agreed upon Kyoto Protocol in 1997 and it entered into force on 16 February 2005. ${ }^{60}$ The Kyoto Protocol extends the main objective of the UNFCCC i.e., "stabilization of greenhouse gas concentrations in the atmosphere at a level that would prevent dangerous anthropogenic interference with the climate system." ${ }^{61}$ In addition, the Protocol places the obligation upon developed countries to reduce emissions, since; they are historically responsible for the current levels of greenhouse gases in the atmosphere. Except the United States of America, all most every country has ratified the treaty. ${ }^{62}$ It is noteworthy that, under the treaty, developing countries, including China, India, Brazil and South Africa were not mandated to reduce emissions, given that these countries only contributed a relatively small share of the current emission of greenhouse gases. ${ }^{63}$

\section{Copenhagen Accord-}

A political accord was struck by world leaders at the U.N. Climate Change Conference in Copenhagen in 2009 which provided for explicit emission pledges by all major economies including, China and other major developing countries but laid down no clear path toward a treaty with binding commitments, which is one of its major criticisms. ${ }^{64}$ The accord was

\footnotetext{
59 'United Nations Framework Convention on Climate Change' (National Atmospheric Emissions Inventory) <http://naei.defra.gov.uk/about/why-we-estimate?view=unfccc> accessed 22 November 2016.

60 'Kyoto Protocol To The United Nations Framework Convention on Climate Change' $<$ https://unfccc.int/resource/docs/convkp/kpeng.pdf> accessed 23 November 2016.

${ }^{61}$ United Nations Framework Convention on Climate Change, art. 2.

62 'What is the Kyoto protocol and has it made any difference?' (The Guardian, March 2011) <https://www.theguardian.com/environment/2011/mar/11/kyoto-protocol> accessed 24 November 2016.

63 'Kyoto Protocol: 10 years of the world's first climate change treaty' (Climate Home, February 2015) $<$ http://www.climatechangenews.com/2015/02/16/kyoto-protocol-10-years-of-the-worlds-first-climate-changetreaty/> accessed 24 November 2016.

$\begin{array}{lllllll}64 & \text { of } & \text { the } & \text { Parties } & \text { to } \\ \text { United } & \text { Natteenth } & \text { Session } & \text { of the } & \text { Conference } \\ \text { Framework } & \text { Convention } & & \text { on } & \text { Climate } & \text { Change }\end{array}$
} 
merely 'recognized' by the 193 countries at the Copenhagen summit, rather than approved in the backdrop of tense negotiations. ${ }^{65}$

\section{Paris Agreement 2015-}

"The Paris agreement which is formally known as the Conference of Parties protocol on fighting climate change, is the world's first comprehensive regime on tackling the phenomenon within the UNFCCC." 66197 countries in Paris adopted the agreement; the agreement will come into force after it has been ratified by at least 55 countries responsible for $55 \%$ of global emissions. The Paris agreement entered into force on 4 November $2016 .{ }^{67}$ "The Paris Agreement's central aim is to strengthen the global response to the threat of climate change by keeping a global temperature rise this century well below 2 degrees Celsius above pre-industrial levels and to pursue efforts to limit the temperature increase even further to 1.5 degrees Celsius. Additionally, the agreement aims to strengthen the ability of countries to deal with the impacts of climate change. To reach these ambitious goals, appropriate financial flows, a new technology framework and an enhanced capacity building framework will be put in place, thus supporting action by developing countries and the most vulnerable countries, in line with their own national objectives. The Agreement also provides for enhanced transparency of action and support through a more robust transparency framework." 68

With respect to India, the Paris agreement is significant in the sense that, India accounts for over $4 \%$ of global emissions and that it will have to reduce its carbon footprint by $33-35 \%$ from its 2005 levels, which has to be achieved by $2030 .^{69}$

\footnotetext{
and Fifth Session of the Meeting of the Parties to the Kyoto Protocol' (Centre for Climate and Energy Solutions) <http://www.c2es.org/international/negotiations/cop-15/summary> accessed 24 November 2016.

65 ibid. - "Key elements of the Copenhagen Accord include: an aspirational goal of limiting global temperature increase to 2 degrees Celsius; a process for countries to enter their specific mitigation pledges by January 31 , 2010; broad terms for the reporting and verification of countries actions; a collective commitment by developed countries for $\$ 30$ billion in "new and additional" resources in 2010-2012 to help developing countries reduce emissions, preserve forests, and adapt to climate change; and a goal of mobilizing $\$ 100$ billion a year in public and private finance by 2020 to address developing county needs. The accord also calls for the establishment of a Copenhagen Green Climate Fund, a High Level Panel to examine ways of meeting the 2020 finance goal, a new Technology Mechanism, and a mechanism to channel incentives for reduced deforestation.”

66 'India and the Paris climate deal' (Livemint, November 2016) <http://www.livemint.com/Politics/o4Q0IO6nSxUiubIAg0MkRK/India-and-the-Paris-climate-agreement-Allyou-need-to-know.html> accessed 24 November 2016.

67 ibid.

68 'The Paris Agreement' <http://unfccc.int/paris_agreement/items/9485.php> accessed 24 November 2016.

69'India and the Paris climate deal' (n 66).
} 


\section{Conclusion:}

The paper has discussed the growing concerns faced by India with regard to climate change. There is an urgent need to enact specific enactments, which address climate change. ${ }^{70}$ Since, the existing legal framework in India lacks heavily when it comes to implementation, appropriate legislations need to be enacted by various State governments to minimize emissions of greenhouse gases and address climate change. It may also be useful to set longterm targets to reduce emissions of these harmful gases. There is also a growing need to deploy resources towards expanding domestic research capacity. This will help in gauging the impacts of climate change in different sectors. At present there is no conclusive research conducted on the impacts of climate change on India. ${ }^{71}$

Other initiatives may include increase in the usage of LED lighting, use of compressed natural gas as fuel, providing for stringent vehicle emission norms and usage of renewable sources of energy. There needs to be a strong national environmental policy which should include clear cut rules with regard to environmental pollution and waste management, while giving licenses to industrial houses. Since vehicles contribute to air pollution in a significant manner, a practical solution needs to be developed to curb this issue. ${ }^{72}$ The State must take initiative to encourage community participation in monitoring pollutions.

As shown in the paper, India has ratified several international conventions relating to Climate Change. But none of the provisions in those international agreements can be implemented by the Indian State per se. India needs to frame new laws to incorporate those provisions in order to implement them to its letter and spirit.

Apart from this, there must be strict penal sanctions to those who do not abide by the laws meant to safeguard the environment and tackle climate change. Where Public Interest Litigations are not filed, the Apex Court can suo moto take up issues of vital importance, which deal with climate change, environmental protection and the impact it has on the poor and the vulnerable. Where the State fails, the Apex Court in its judicial capacity can make laws, which will be binding on all. Only when the State, Judiciary and Civil society join hands, climate change can be tackled to a large extent and the impact it has on the people, especially the marginalized can be lessened to a minimum.

\footnotetext{
${ }^{70}$ Saha and Talwar (n 10) 186.

${ }^{71}$ Saha and Talwar (n 10) 187.

72 Saha and Talwar (n 10) 187, 188; Kasturi Das and Kaushik Bandyopadhyay, Climate Change Adaptation in the Framework of Regional Cooperation in South Asia (2015) 1 CCLR 40, 50.
} 